\title{
Attention-Deficit/Hyperactivity Disorder in Looked-After Children: a Systematic Review of the Literature
}

\author{
Renece Willis $^{1} \cdot$ Suyog Dhakras $^{2} \cdot$ Samuele Cortese $^{1,2,3,4}$ \\ Published online: 18 July 2017 \\ (C) The Author(s) 2017. This article is an open access publication, Corrected publication August/2017
}

\begin{abstract}
Purpose of review To systematically review the literature on the prevalence and pharmacological treatment of ADHD in looked-after children (LAC).

Recent findings LAC are a very challenging population from a clinical and psychosocial standpoint, with higher mental health needs compared to non LAC. To date, no systematic review on the prevalence of $\mathrm{ADHD}$, and its treatment, in LAC is available.

Summary We searched Pubmed, PsycInfo EMBASE + EMBASE CLASSIC, OVID Medline and Web of Science up to November 9 th, 2016. We found 24 papers meeting our criteria. The vast majority of the retained studies are from the USA and show rates of ADHD and of its pharmacological treatment substantially higher in LAC than those reported in national estimates. Future studies from countries other than the USA, aiming to understand the most cost-effective strategies, in the short as well as long term, to manage symptoms of ADHD in LAC are needed.
\end{abstract}

The original version of this article was revised: a modification has been made to the name of the second author. The correct name of the second author can also be found in the erratum for this article.

This article is part of the Topical Collection on $A D H D$

Electronic supplementary material The online version of this article (doi:10.1007/s40474-017-0116-z) contains supplementary material, which is available to authorized users.

Samuele Cortese

samuele.cortese@gmail.com

1 Academic Unit of Psychology, University of Southampton, Southampton, UK

2 Solent NHS Trust, Southampton, UK

3 Clinical and Experimental Sciences (CNS and Psychiatry), Faculty of Medicine, University of Southampton, Southampton, UK

4 The Child Study Center, New York University Langone Medical Center, New York, NY 10016, USA
Keywords ADHD · Looked-after children · Psychostimulants

\section{Introduction}

Attention-deficit/hyperactivity disorder (ADHD) is characterized by impairing, persistent and pervasive levels of inattention and/or hyperactivity/impulsivity [1]. With an estimated worldwide prevalence of around 5\% [2], ADHD is one of the most commonly diagnosed neurodevelopmental disorders. ADHD is frequently comorbid with other conditions such as oppositional defiant disorder, conduct disorder, specific learning disorders, mood and anxiety disorders, substance use disorders, sleep disturbances and other neurodevelopmental disorders such as autism spectrum disorder [3-8], as well as with somatic conditions such as obesity $[6,9,10]$.

ADHD is a complex and heterogeneous disorder in terms of brain correlates, characterized by a dysfunctional interplay among several neuronal networks [11]. Its aetiology is accounted for by an interaction of genetic and environmental factors, the most common ones being prematurity, low birth weight and maternal smoking or alcohol during pregnancy [12].

Available treatments for ADHD include pharmacological and non-pharmacological interventions. Medications for ADHD comprise psychostimulant (e.g. methylphenidate and amphetamine derivatives) and non-psychostimulant drugs (e.g. atomoxetine, clonidine and guanfacine). A large body of evidence shows that ADHD medications are efficacious, at least in the short and medium terms, to control ADHD core symptoms [13, 14]. Non-pharmacological options for ADHD include, among others, parent training programmes, diet interventions, cognitive training and neurofeedback. Available evidence indicates that whilst the value of these interventions for 
ADHD core symptoms remains uncertain [15-18], they can effectively address associated conditions, such as oppositional behaviours in the case of parent training programmes [19].

Whilst ADHD has been extensively investigated in particular populations, such as preterm children or individuals in prisons, it has been neglected in others, such as looked-after children (LAC).

LAC are defined as those children who are being provided with substitute care [20]. The term "looked-after" is often used when referring to children who are in public care. Thus, LAC are inclusive of children in foster care, as well as children who are living with their parents but are subjected to care orders [21].

LAC are representative of a very challenging and complex population. Children in residential care settings are generally regarded as having greater mental health needs, in comparison to the general population of the same age [22]. According to House of Commons Education Committee [23], 42\% of LAC aged between 5 and 10 years old in the UK were affected by a mental illness, as opposed to only $8 \%$ in the general population in that same age category. The study further noted that $49 \%$ of LAC aged between 11 and 15 were affected by a mental illness, with only $13.5 \%$ in the same age category in the general population. Additionally, $13.5 \%$ of children in care were using psychotropic medications; this figure stood three times higher in comparison to children living with their birth families [23]. Children entering foster care are generally in poor mental health not only as a result of risk factors such as parental mental illnesses or poverty, but also because of the fact that there is inadequate medical provision before entering into care.

Among the psychopathological risks that LAC are prone to, it has been reported that children in foster care are more prone to experiencing psychosocial (such as dysfunctional family dynamics) and biological risk factors (such as maternal smoking or use of alcohol during pregnancy) before and during their stay in care that makes them more susceptible to hyperactivity, impulsivity and inattention.

To our knowledge, literature on the prevalence and characteristics of ADHD, including its treatment, in LAC has not been systematically reviewed. Gaining insight into the prevalence of the diagnosis of ADHD in LAC, as well as of the rates of prescription of ADHD medication, is of relevance from a clinical as well as public health standpoint. The aim of this paper is to fill this gap, in order to provide relevant and updated information to patients, clinicians and managers when designing clinical pathways for the care of LAC.

\section{Methods}

Methods were developed according to Preferred Reporting Items for Systematic Reviews and Meta-Analyses (PRISMA) [24] recommendations.

\section{Search Strategy}

We searched the following electronic databases: PubMed, PsycInfo, Embase + Embase Classic, Ovid MEDLINE and Web of Sciences databases, with no language restrictions, from inception to November 9, 2016. The search terms and syntax for PubMed were as follows: (ADHD [tiab] OR Attention-deficit/hyperactivity disorder [tiab] OR attention deficit disorder with hyperactivity [tiab] OR Attention deficit [tiab] OR hyperkinetic disorder [tiab] OR hyperkinetic syndrome [tiab]) AND ("looked after children" [tiab] OR "foster care" [tiab] OR "residential setting" [tiab]). The search terms and syntax were adapted for the other databases and are reported in the Supplemental Material. We also searched bibliographic references from relevant papers.

We retained peer-reviewed, empirical quantitative studies providing information on the prevalence of ADHD, and/of its treatment, in LAC. We excluded case reports, case series, qualitative studies or non-peer-reviewed publications. As for the diagnosis of ADHD, we included studies based on a formal diagnosis of ADHD as per the Diagnostic and Statistical Manual of Mental Disorders (DSM), III, III-R, IV, IV-TR or 5 or the International Classification of Diseases (ICD), 10th edition, or studies where ADHD was defined based on scores above a cut-off on a validated ADHD questionnaire.

\section{Results}

From an initial pool of 350 possibly relevant references, we retained 24 studies meeting our criteria (Supplemental Material). The details of the selection process are reported in Fig. 1, which shows the PRISMA flowchart. Table 1 summarizes the characteristics of studies reporting data on the prevalence of ADHD in LAC. Table 2 reports the characteristics of studies with data on the rates of medications to treat symptoms of ADHD in LAC. As shown in the tables, the vast majority of the studies retained in the systematic review were conducted in the USA and adopted a cross-sectional design. Sample sizes of LAC participants varied substantially across studies, from 87 to 51.500. Diagnostic procedures for ADHD were also heterogeneous across studies.

As for the prevalence of ADHD, only a minority of studies contrasted LAC and non-LAC, showing higher rates in LAC. The rest of the studies reported the prevalence of ADHD in LAC (without comparison to a non-LAC group), which was substantially higher than the national prevalence of ADHD in the study country [25]. Indeed, due to heterogeneity in the procedures to estimate ADHD rates, the prevalence of ADHD or risk for ADHD ranged from 3.8 to $68 \%$. The rates of ADHD pharmacological treatment ranged from 22 to $81 \%$. Likewise, across studies, the prevalence of ADHD 
Fig. 1 PRISMA flowchart illustrating study selection process

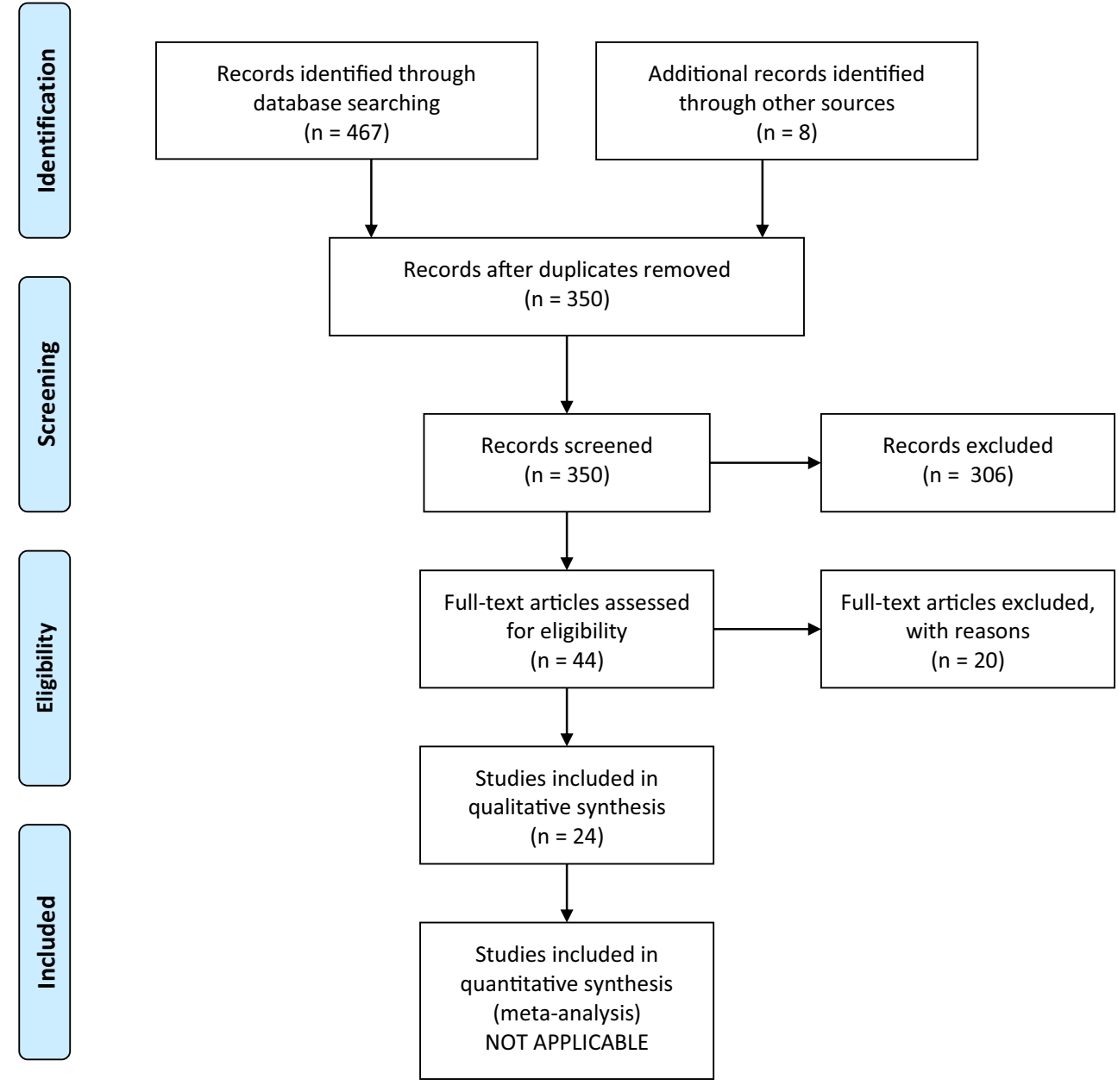

pharmacological treatment was substantially higher than national estimates [26].

\section{Discussion}

To our knowledge, this is the first systematic review aimed at comprehensively assessing the literature on the prevalence of ADHD, and its pharmacological treatment, in LAC.

Given the complex nature of the clinical presentation of LAC and their needs, some authors have reported concerns that ADHD might be under diagnosed in LAC, missing out on appropriate treatment [27]. However, the results of our systematic review would suggest that this is not the case, at least in the USA, where the vast majority of the studies retained in our systematic review were conducted. Nonetheless, the difference in the prevalence across studies is striking. In our view, such heterogeneity is accounted for by several factors. First, it should be noted that the tools and criteria for the assessment of ADHD varied across studies. More specifically, whilst some studies used a rigorous diagnosis according to formal ADHD criteria (as per DSM or ICD), other used a cut-off above a certain threshold on a validated ADHD questionnaire. Furthermore, the use of DSM or ICD may have introduced further heterogeneity, since the equivalent ICD diagnosis for ADHD (hyperkinetic syndrome) represents a more restricted category compared to the DSM ADHD. Beyond these important methodological factors, in our view, an additional source of heterogeneity across studies is represented by a possible discrepancy conceptualization of symptoms of hyperactivity, inattention and/or impulsivity in LAC. In particular, at least in some countries, these symptoms tend or at least tended to be considered as an expression of attachment disorder, rather than reflecting core symptoms of a primarily neurobiological or neurological disorder. In this regard, it is worthy to note that in the only study retained in our systematic review conducted in France [28], the prevalence of ADHD in LAC $(3.8 \%)$ was clearly lower than that reported in the studies from the USA. It is interesting to note that child psychiatry and provision of child mental health in France have been strongly influenced by psychoanalytic models [29], which would contribute to practitioners formulate the symptoms of inattention, hyperactivity and impulsivity as being an expression of attachment issues, rather than of a primary ADHD. Indeed, the 
Table 1 Studies reporting data on the prevalence of ADHD in LAC

\begin{tabular}{|c|c|c|c|c|c|c|}
\hline $\begin{array}{l}\text { First author } \\
\text { (year) }\end{array}$ & Country & Design & $\begin{array}{l}\text { Sample size } \\
(N \text { of youth } \\
\text { in foster } \\
\text { care })\end{array}$ & $\begin{array}{l}\text { Age } \\
\text { (years) }\end{array}$ & $\begin{array}{l}\text { Diagnosis of ADHD } \\
\text { (tools and/or criteria) }\end{array}$ & Key findings \\
\hline $\begin{array}{r}\text { Bronsard } \\
(2011)\end{array}$ & France & Cross sectional & 183 & $13-17$ & $\begin{array}{l}\text { DSM-III-R Diagnostic } \\
\text { Interview Schedule for } \\
\text { Children (DISC 2.25) }\end{array}$ & $\begin{array}{l}\text { Prevalence of ADHD in LAC } 3.8 \% \text { (previous } \\
\text { estimate of ADHD prevalence in the general } \\
\text { population in France } 2 \% \text { ). }\end{array}$ \\
\hline $\begin{array}{r}\text { Dos Reis } \\
\text { (2001) }\end{array}$ & USA & Cross sectional & 310 & $<19$ & ICD-9-CM & $\begin{array}{l}\text { Comparison of } 3 \text { groups with ADHD: those in } \\
\text { foster care, those receiving Supplemental } \\
\text { Security Income (SSI) and those receiving other } \\
\text { aids. Prevalence of ADHD in youth in foster } \\
\text { care, those receiving Supplemental Security } \\
\text { Income (SSI) and those receiving other aids } 16 \text {, } \\
7,0.8 \% \text {, respectively. }\end{array}$ \\
\hline $\begin{array}{r}\text { Dos Reis } \\
(2011)\end{array}$ & USA & Cross sectional & $\begin{array}{l}2310(1075 \\
\text { with } \\
\text { ADHD) }\end{array}$ & $<20$ & ICD-9 revision & $\begin{array}{l}\text { Comparison of } 3 \text { groups with ADHD: those with } \\
\text { foster care, those with low income and those } \\
\text { with federally documented disability. } \\
\text { Prevalence of ADHD diagnosis: foster care, } \\
\quad 46.5 \% \text {; disabled, } 56 \% \text {; and low income, } 52 \% \text {. }\end{array}$ \\
\hline $\begin{array}{l}\text { Garland } \\
\text { (2001) }\end{array}$ & USA & Longitudinal & 1618 & $16-18$ & $\begin{array}{l}\text { DSM-III-R Computerized } \\
\text { Diagnostic Interview } \\
\text { Schedule for Children } \\
\text { (C-DISC 2.25) }\end{array}$ & $\begin{array}{l}\text { Prevalence of ADHD in child in welfare } 21 \% \\
\text { (prevalence of with ADHD/disruptive } \\
\text { behaviour disorder } 38.7 \% \text { ) }\end{array}$ \\
\hline $\begin{array}{l}\text { Goodman } \\
\quad(2004)\end{array}$ & UK & Cross-sectional & 1028 & $5-17$ & $\begin{array}{l}\text { Prediction of diagnoses based } \\
\text { on the Strength and } \\
\text { Difficulties Questionnaire } \\
\text { (SDQ) }\end{array}$ & $68 \%$ of LAC detected as at risk for ADHD. \\
\hline $\begin{array}{l}\text { Harman } \\
\quad(2000)\end{array}$ & USA & Cross-sectional & 3696 & $5-17$ & ICD-9-CM & $\begin{array}{l}\text { Prevalence of ADHD in LAC, children in "Aid to } \\
\text { Families with Dependent Children" and } \\
\text { children in Supplemental Security Income 14.7, } \\
3.9 \text { and } 19.8 \% \text {, respectively. }\end{array}$ \\
\hline $\begin{array}{l}\text { Heneghan } \\
\quad(2013)\end{array}$ & USA & Longitudinal & 815 & $12-15$ & $\begin{array}{l}\text { Scores above cut-off in the } \\
\text { Child Behavior Checklist } \\
\text { (CBCL) and Youth } \\
\text { Self-Report (YSR) }\end{array}$ & Prevalence of ADHD in LAC $18.5 \%$. \\
\hline $\begin{array}{l}\text { Humphreys } \\
\text { (2015) }\end{array}$ & Romania & $\begin{array}{l}\text { Longitudinal } \\
\text { Cohort }\end{array}$ & 110 & 12 & $\begin{array}{l}\text { Diagnostic Interview Schedule } \\
\text { for Children (4th edition; } \\
\text { DISC-IV) }\end{array}$ & $\begin{array}{l}\text { Children who had been institutionalized displayed } \\
\text { higher rates of externalizing disorders such as } \\
\text { ADHD ( } 4.00 \text { vs. } 0.71 \text { in comparison to those } \\
\text { who were not). }\end{array}$ \\
\hline Jee $(2011)$ & USA & Cross sectional & 138 & $11-17$ & $\begin{array}{l}\text { Prediction of diagnoses based } \\
\text { on the Strength and } \\
\text { Difficulties Questionnaire } \\
\text { (SDQ) }\end{array}$ & $\begin{array}{l}\text { Risk for ADHD according to parents and youth } 13 \\
\text { and } 8 \% \text {, respectively. }\end{array}$ \\
\hline $\begin{array}{r}\text { Lehmann } \\
\text { (2013) }\end{array}$ & Norway & Cross sectional & 279 & $6-12$ & $\begin{array}{l}\text { Development and Well-Being } \\
\text { Assessment (DAWBA) } \\
\text { Development and Well-Being } \\
\text { Assessment (DAWBA) } \\
\text { DSM-IV criteria }\end{array}$ & Prevalence of ADHD in LAC $19 \%$. \\
\hline $\begin{array}{l}\text { Linares }(2010, \\
\text { 2013) }\end{array}$ & USA & Longitudinal & 252 & $3-12$ & $\begin{array}{l}\text { Diagnostic Interview Schedule } \\
\text { for Children (4th edition; } \\
\text { DISC-IV). }\end{array}$ & Prevalence of ADHD in LAC 55\%. \\
\hline $\begin{array}{l}\text { McMillen } \\
\quad(2005)\end{array}$ & USA & Cross sectional & 373 & 17 & $\begin{array}{l}\text { Diagnostic Interview Schedule } \\
\text { for DSM-IV }\end{array}$ & Prevalence of ADHD in LAC $20 \%$. \\
\hline $\begin{array}{l}\text { Raghavan } \\
\text { (2008) }\end{array}$ & USA & Cross sectional & 406 & 17 & $\begin{array}{l}\text { Diagnostic Interview Schedule } \\
\text { IV (DIS 5) }\end{array}$ & $\begin{array}{l}\text { Prevalence of ADHD in those leaving foster care } \\
10.5 \% \text {. }\end{array}$ \\
\hline $\begin{array}{l}\text { Vanderwerker } \\
\text { (2014) }\end{array}$ & USA & Cross sectional & 301.894 & $<18$ & ICD-9-CM & $\begin{array}{l}\text { Prevalence of ADHD in LAC } 17.3 \text { vs. } 6.5 \% \text { in } \\
\text { non-foster care youth. }\end{array}$ \\
\hline Zito (2008) & USA & Cross sectional & 472 & $0-19$ & ICD-9 & $\begin{array}{l}\text { Prevalence of clinician reported diagnosis of } \\
\text { ADHD in LAC } 38.8 \% \text {. }\end{array}$ \\
\hline
\end{tabular}

Studies are listed in alphabetical order 
Table 2 Studies providing data on the rates of medications for ADHD symptoms (and related symptoms) in LAC

\begin{tabular}{|c|c|c|c|c|c|c|}
\hline $\begin{array}{l}\text { First } \\
\text { author } \\
\text { (year) }\end{array}$ & Country & Design & $\begin{array}{l}\text { Sample size } \\
(N \text { of youth } \\
\text { in } \\
\text { foster care })\end{array}$ & $\begin{array}{l}\text { Age } \\
\text { (years) }\end{array}$ & $\begin{array}{l}\text { Diagnosis of ADHD } \\
\text { (tools and/or criteria) }\end{array}$ & Key findings \\
\hline $\begin{array}{l}\text { Burcu } \\
\quad(2014)\end{array}$ & USA & Cross sectional & 1338 & $2-17$ & ICD-9 & $\begin{array}{l}\text { Rates of atypical antipsychotic use in youth in foster care } \\
\text { more than threefold greater than those enrolled in } \\
\text { income-eligible Medicaid categories. }\end{array}$ \\
\hline $\begin{array}{l}\text { Chen } \\
\text { (2009) }\end{array}$ & USA & Cross sectional & 4129 & $<21$ & ICD-9-CM & $\begin{array}{l}\text { The rates of pharmacological treatment with ADHD } \\
\text { medications was significantly higher in youth in foster } \\
\text { care compared to those not in foster care (OR }=1.11 \text {, } \\
1.02-1.20)\end{array}$ \\
\hline $\begin{array}{r}\text { Dos Reis } \\
(2004)\end{array}$ & USA & Cross sectional & $\begin{array}{l}87 \text { with } \\
\text { ADHD }\end{array}$ & $<20$ & ICD-9 & $\begin{array}{l}\text { Comparison of } 3 \text { groups with ADHD: those in foster care } \\
\text { those with low income and those with federally } \\
\text { documented disability. } \\
\text { Rates of ADHD medication use: foster care, } 81 \% \text {; } \\
\quad \text { disabled, } 88 \% \text {; and low income, } 83 \% \text {. }\end{array}$ \\
\hline $\begin{array}{r}\text { Dos Reis } \\
(2011)\end{array}$ & USA & Cross sectional & $\begin{array}{l}2310(1075 \\
\text { with } \\
\text { ADHD) }\end{array}$ & $<20$ & ICD-9 revision & $\begin{array}{l}\text { Comparison of } 3 \text { groups with ADHD: those with foster } \\
\text { care, those with low income and those with federally } \\
\text { documented disability } \\
\text { Rates of ADHD medication use: foster care, } 49.5 \% \text {; } \\
\quad \text { disabled, } 57.8 \% \text {; and low income, } 54.8 \% \text {. }\end{array}$ \\
\hline $\begin{array}{r}\text { Dos Reis } \\
(2014)\end{array}$ & USA & Retrospective & 1491 & $\leq 6$ & & $\begin{array}{l}\text { Rates of ADHD medication prescription: age } 3,<1 \% \text {; age } \\
\quad 4,7 \% \text {; age } 5,15 \% \text {; and age } 6,22 \% \text {. }\end{array}$ \\
\hline $\begin{array}{r}\text { Dos Reis } \\
(2001)\end{array}$ & USA & Cross sectional & 310 & $<19$ & ICD-9-CM & $\begin{array}{l}\text { Comparison of } 3 \text { groups with ADHD: those in foster care } \\
\text { those receiving Supplemental Security Income (SSI) } \\
\text { and those receiving other aids. } \\
\text { Rates of psychostimulant use in youth in foster care, those } \\
\text { receiving Supplemental Security Income (SSI) and } \\
\text { those receiving other aids: } 18,5 \text { and } 1 \% \text {, respectively }\end{array}$ \\
\hline $\begin{array}{r}\text { Ferguson } \\
(2006)\end{array}$ & USA & Retrospective & 473 & $<18$ & Not specified & Rates of stimulants use $56 \%$ \\
\hline $\begin{array}{l}\text { Kamble } \\
\text { (2015) }\end{array}$ & USA & $\begin{array}{l}\text { Retrospective } \\
\text { longitudinal } \\
\text { analysis }\end{array}$ & 9.448 & $6-17$ & ICD-9-CM & $\begin{array}{l}\text { LAC had nearly twice the odds }(\mathrm{OR}=1.83) \text { of non-foste } \\
\text { care children of receiving long-acting stimulants and } \\
\text { second-generation antipsychotics concurrently. }\end{array}$ \\
\hline $\begin{array}{l}\text { Kreider } \\
\quad(2014)\end{array}$ & USA & $\begin{array}{l}\text { Repeated } \\
\text { cross-- } \\
\text { sectional } \\
\text { design }\end{array}$ & 51.500 & $6-18$ & & $\begin{array}{l}\text { Rates of stimulant use in } 2004 \text { and 2008, respectively, } 21.1 \\
\text { and } 22.8 \% \text {. }\end{array}$ \\
\hline $\begin{array}{l}\text { Linares } \\
\quad(2010 \\
\text { 2013) }\end{array}$ & USA & Longitudinal & 252 & $3-12$ & $\begin{array}{l}\text { Diagnostic Interview } \\
\text { Schedule for Children } \\
\text { (4th edition; DISC-IV). }\end{array}$ & Rate of stimulant use in LAC $38 \%$. \\
\hline $\begin{array}{c}\text { Raghavan } \\
\text { (2008) }\end{array}$ & USA & Cross sectional & 406 & 17 & $\begin{array}{l}\text { Diagnostic Interview } \\
\text { Schedule IV (DIS 5) }\end{array}$ & Rates of stimulant use in LAC $59 \%$. \\
\hline $\begin{array}{l}\text { Zima } \\
\text { (1999) }\end{array}$ & USA & Cross sectional & 302 & $6-12$ & $\begin{array}{l}\text { Child and Adolescent } \\
\text { Functioning Assessment } \\
\text { Scale (CAFAS), DSM-IV }\end{array}$ & Rate of psychostimulant use in the past year in LAC $62 \%$ \\
\hline $\begin{array}{l}\text { Zito } \\
\text { (2008) }\end{array}$ & USA & Cross sectional & 472 & $0-19$ & ICD-9 & $\begin{array}{l}\text { ADHD drugs (amphetamine, methylphenidate, others) in } \\
55.9 \% \text { of participants. }\end{array}$ \\
\hline
\end{tabular}

Studies are listed in alphabetical order

debate about the relationship between ADHD and attachment disorder is one of the most interesting ones in child psychopathology [30], but we believe also one of the less supported by evidence base. Whilst ADHD and attachment issues may be viewed as alternative constructs [31], it is also possible to conceptualize attachment issue as a risk factor contributing to ADHD [32].
Another concern is that ADHD is over diagnosed in LAC. This would particularly be favoured by misdiagnosing ADHD-like symptoms accounted for by disorders other than ADHD (e.g. anxiety, frequent in LAC) as "real" ADHD. In this regard, the use of the ICD category of hyperkinetic syndrome, which is ruled out in the presence of other disorders such as anxiety that can manifest with ADHD-like symptoms, 
would tend to reduce the risk of over diagnosis. However, rather than under or over diagnosis, in our view, the main issue is to which extent ADHD is correctly diagnosed in LAC, limiting false-positive as well as false-negative cases. Comparative studies across countries will be of interest in this respect.

Similarly to the prevalence of ADHD, the rate of ADHD medication prescription was general high across studies and higher than the national estimates of the use of ADHD drugs [26]. Data on the use of ADHD medication from each study should be interpreted with caution, since some of the studies reported lifetime prevalence, whilst others focused on actual prevalence. Furthermore, whilst some studies focused on psychostimulants or methylphenidate, others included several classes of ADHD medications (e.g. atomoxetine). Whilst over prescription is clearly a concern, in view of the potential side effects of ADHD medications (although in most cases, these are manageable), we believe that appropriate prescription is the key. Indeed, preliminary evidence shows the potential benefit of ADHD medications in LAC. A Danish study concluded that the decline in foster care caseloads in the period 1998-2010 would have been 45\% smaller without a pharmacological treatment of ADHD [33].

Our work should be considered in the light of study strengths and limitations. Among the strengths, we highlight that we conducted a comprehensive search across a large set of databases and with no language/date restrictions. The main limitation is represented by the heterogeneity in the methodology across studies, which prevented us from conducting a formal meta-analysis based on the data retrieved in the studies retained in our systematic review.

In conclusion, this systematic review showed high prevalence of ADHD and high rates of ADHD pharmacological treatment in LAC, at least in the USA. Further methodologically sound research is needed from other countries. Perhaps more importantly, rather than assessing if ADHD is over or under diagnosed and treated in LAC, future research should aim to understand to which extent ADHD is appropriately diagnosed and treated in LAC and which are the most cost-effective strategies, in the short as well as long term, to manage symptoms of ADHD in LAC.

\section{Compliance with Ethical Standards}

Conflict of Interest The authors declare that they have no competing interests.

Human and Animal Rights and Informed Consent This article does not contain any studies with human or animal subjects performed by any of the authors.
Open Access This article is distributed under the terms of the Creative Commons Attribution 4.0 International License (http:// creativecommons.org/licenses/by/4.0/), which permits unrestricted use, distribution, and reproduction in any medium, provided you give appropriate credit to the original author(s) and the source, provide a link to the Creative Commons license, and indicate if changes were made.

\section{References}

1. American Psychiatric Association. Diagnostic and Statistical Manual of Mental Disorders, Fifth Edition, DSM-5. American Psychiatric Publishing ed., 2013.

2. Polanczyk G, de Lima MS, Horta BL, Biederman J, Rohde LA. The worldwide prevalence of ADHD: a systematic review and metaregression analysis. Am J Psychiatry. 2007;164:942-8.

3. Biederman J, Faraone SV. Attention-deficit hyperactivity disorder. Lancet. 2005;366:237-48.

4. Cortese S, Holtmann M, Banaschewski T, Buitelaar J, Coghill D, Danckaerts M, et al. Practitioner review: current best practice in the management of adverse events during treatment with ADHD medications in children and adolescents. J Child Psychol Psychiatry. 2013;54:227-46.

5. Asch M, Cortese S, Perez DF, Pelissolo A, Aubron V, Orejarena S, et al. Psychometric properties of a French version of the junior temperament and character inventory. Eur Child Adolesc Psychiatry. 2009;18:144-53.

6. Cortese S, Konofal E, Lecendreux M. Alertness and feeding behaviors in ADHD: does the hypocretin/orexin system play a role? Med Hypotheses. 2008;71:770-5.

7. Purper-Ouakil D, Cortese S, Wohl M, Aubron V, Orejarena S, Michel G, et al. Temperament and character dimensions associated with clinical characteristics and treatment outcome in attention-deficit/hyperactivity disorder boys. Compr Psychiatry. 2010;51:28692.

8. Lecendreux M, Cortese S. Sleep problems associated with ADHD: a review of current therapeutic options and recommendations for the future. Expert Rev Neurother. 2007;7:1799-806.

9. Cortese S, Castellanos FX. The relationship between ADHD and obesity: implications for therapy. Expert Rev Neurother. 2014;14: 473-9.

10. Cortese S, Moreira-Maia CR, St FD, Morcillo-Penalver C, Rohde LA, Faraone SV. Association between ADHD and obesity: a systematic review and meta-analysis. Am J Psychiatry. 2016;173:3443.

11. Cortese S, Castellanos FX. Neuroimaging of attention-deficit/hyperactivity disorder: current neuroscience-informed perspectives for clinicians. Curr Psychiatry Rep. 2012;14:568-78.

12. Faraone SV, Asherson P, Banaschewski T, Biederman J, Buitelaar JK, Ramos-Quiroga JA, et al. Attention-deficit/hyperactivity disorder. Nat Rev Dis Primers. 2015;1:15020.

13. Banaschewski T, Buitelaar J, Chui CS, Coghill D, Cortese S, Simonoff E, et al. Methylphenidate for ADHD in children and adolescents: throwing the baby out with the bathwater. Evid Based Ment Health. 2016;19:97-9.

14. De Crescenzo F, Cortese S, Adamo N, Janiri L. Pharmacological and non-pharmacological treatment of adults with ADHD: a metareview. Evidence based mental Health. 2017;20(1):4-11.

15. Cortese S, Ferrin M, Brandeis D, Buitelaar J, Daley D, Dittmann $\mathrm{RW}$, et al. Cognitive training for attention-deficit/hyperactivity disorder: meta-analysis of clinical and neuropsychological outcomes from randomized controlled trials. J Am Acad Child Adolesc Psychiatry. 2015;54:164-74. 
16. Cortese S, Ferrin M, Brandeis D, Holtmann M, Aggensteiner P, Daley D, et al. Neurofeedback for attention-deficit/hyperactivity disorder: meta-analysis of clinical and neuropsychological outcomes from randomized controlled trials. J Am Acad Child Adolesc Psychiatry. 2016;55:444-55.

17. Sonuga-Barke EJ, Brandeis D, Cortese S, Daley D, Ferrin M, Holtmann M, et al. Nonpharmacological interventions for ADHD: systematic review and meta-analyses of randomized controlled trials of dietary and psychological treatments. Am J Psychiatry. 2013;170:275-89.

18. Stevenson J, Buitelaar J, Cortese S, Ferrin M, Konofal E, Lecendreux M, et al. Research review: the role of diet in the treatment of attention-deficit/hyperactivity disorder-an appraisal of the evidence on efficacy and recommendations on the design of future studies. J Child Psychol Psychiatry. 2014;55(5):416-27.

19. Daley D, Van der Oord S, Ferrin M, Danckaerts M, Doepfner M, Cortese S, et al. Behavioral interventions in attention-deficithyperactivity disorder: a meta-analysis of randomized controlled trials across multiple outcome domains. J Am Acad Child Adolesc Psychiatry. 2014;53:835-47.

20. McAuley C, Davis T. Emotional well-being and mental health of looked after children in England. 2009; 147-155.

21. Richardson LP. Mental health of looked after children. Adv Psychiatr Treat. 2003;9:249-51.

22. William Utting. People like us: the report of the review of the safeguards for children living away from home, DoH/Welsh Office, 1997 https://www.publications.parliament.uk/pa/ cm201516/cmselect/cmeduc/481/481.pdf:

23. Raghavan R, Zima BT, Andersen RM, Leibowitz AA, Schuster MA, Landsverk J. Psychotropic medication use in a national probability sample of children in the child welfare system. J Child Adolesc Psychopharmacol. 2005;15:97-106.
24. Liberati A, Altman DG, Tetzlaff J, Mulrow C, Gotzsche PC, Ioannidis JP, et al. The PRISMA statement for reporting systematic reviews and meta-analyses of studies that evaluate healthcare interventions: explanation and elaboration. BMJ. 2009;339:b2700.

25. Polanczyk GV, Willcutt EG, Salum GA, Kieling C, Rohde LA. ADHD prevalence estimates across three decades: an updated systematic review and meta-regression analysis. Int $\mathrm{J}$ Epidemiol. 2014;43(2):434-42.

26. Taylor E. Uses and misuses of treatments for ADHD. The second Birgit Olsson lecture. Nord J Psychiatry. 2014;68:236-42.

27. Woolgar M, Baldock E. Attachment disorders versus more common problems in looked after and adopted children: comparing community and expert assessments. Child Adoelsc Mental Health. $2015 ; 4$

28. Bronsard G, Lancon C, Loundou A, Auquier P, Rufo M, Simeoni MC. Prevalence rate of DSM mental disorders among adolescents living in residential group homes of the French Child Welfare System. Child Youth Serv Rev. 2011;33(10):1886-90.

29. Forgeot DB, Cortese S, Pinabel F, Purper-Ouakil D. Manifest for evidence-based child psychiatry in France. Eur Child Adolesc Psychiatry. 2013;22:53-4.

30. Franc N, Maury M, Purper-Ouakil D. ADHD and attachment processes: are they related? Encéphale. 2009;35:256-61.

31. Kissgen R, Franke S. An attachment research perspective on ADHD. Neuropsychiatrie. 2016;30:63-8.

32. Storebo OJ, Rasmussen PD, Simonsen E. Association between insecure attachment and ADHD: environmental mediating factors. J Atten Disord. 2016;20:187-96.

33. Fallesen P, Wildeman C. The effect of medical treatment of attention deficit hyperactivity disorder (ADHD) on foster care caseloads: evidence from Danish registry data. J Health Soc Behav. 2015;56: 398-414. 